\title{
Replacement compared with anterior discectomy and fusion for treatment of 2-level symptomatic degenerative disc disease: a prospective, randomized, controlled, multicenter investigational device exemption clinical trial
}

TO THE READERSHIP: An error occurred during production of a recent paper by Kris Radcliff, MD, Domagoj Coric, MD, and Todd Albert, MD (J Neurosurg Spine [epub ahead of print March 25, 2016; DOI: 10.3171/2015.12.SPINE15824]). The title was truncated, rendering it senseless.

The erroneous title, as first published, was

Replacement compared with anterior discectomy and fusion for treatment of 2-level symptomatic degenerative disc disease: a prospective, randomized, controlled, multicenter investigational device exemption clinical trial.

The corrected title is

Five-year clinical results of cervical total disc replacement compared with anterior discectomy and fusion for treatment of 2-level symptomatic degenerative disc disease: a prospective, randomized, controlled, multicenter investigational device exemption clinical trial.

We apologize to Drs. Radcliff, Coric, and Albert, as well as to the readers for this error. The title of the paper has been corrected as of April 8, 2016.

Gillian Shasby

Director of Publications-Operations Journal of Neurosurgery Publishing Group, Charlottesville, VA

CORRESPONDING ARTICLE See pp 213-224.

INCLUDE WHEN CITING

Published online April 8, 2016; DOI: 10.3171/2016.3.SPINE15824a.

(c)AANS, 2016 